\title{
CD26-positive/CD326-negative circulating cancer cells as prognostic markers for colorectal cancer recurrence
}

\author{
EVA LIETO $^{1}$, GENNARO GALIZIA ${ }^{1}$, MICHELE ORDITURA ${ }^{2}$, CIRO ROMANO $^{3}$, ANNA ZAMBOLI $^{1}$, \\ PAOLO CASTELLANO $^{1}$, ANDREA MABILIA ${ }^{1}$, ANNAMARIA AURICCHIO ${ }^{1}$, \\ FERDINANDO DE VITA $^{2}$ and MARICA GEMEI ${ }^{4}$
}

\author{
${ }^{1}$ Division of Surgical Oncology, Department of Anesthesiological, Surgical and Emergency Sciences; \\ ${ }^{2}$ Division of Medical Oncology, 'F. Magrassi-A. Lanzara' Department of Clinical and Experimental Medicine and Surgery; \\ ${ }^{3}$ Division of Internal Medicine, Allergy and Clinical Immunology, Department of Medical and Surgical Sciences, \\ Second University of Naples School of Medicine, Naples I-80131; ${ }^{4}$ Center for Genetic Engineering, \\ Advanced Biotechnologies, Naples I-80145, Italy
}

Received December 17, 2013; Accepted July 18, 2014

DOI: $10.3892 / \mathrm{ol} .2014 .2749$

\begin{abstract}
The present study evaluated the presence and clinical relevance of a cluster of differentiation (CD) $26^{+} / \mathrm{CD} 326^{-}$subset of circulating tumor cells (CTCs) in pre- and post-operative blood samples of colorectal cancer patients, who had undergone curative or palliative intervention, in order to find a novel prognostic factor for patient management and follow-up. In total, 80 colorectal cancer patients, along with 25 healthy volunteers were included. The easily transferable methodology of flow cytometry, along with multiparametric antibody staining were used to selectively evaluate CD26 ${ }^{+} / \mathrm{CD} 326^{-}$CTCs in the peripheral blood samples of colorectal cancer patients. The multiparametric selection allowed any enrichment methods to be avoided thus rendering the whole procedure suitable for clinical routine. The presence of CD26 ${ }^{+}$CD $326^{-}$cells was higher in advanced Dukes' stages and was significantly associated with poor survival and high recurrence rates. Relapsing and non-surviving patients showed the highest number of CD26 ${ }^{+}$CD $326^{-}$CTCs. High pre-operative levels of $\mathrm{CD}^{2} 6^{+} / \mathrm{CD} 326^{-} \mathrm{CTC}$ correctly predicted tumor relapse in $44.4 \%$ of the cases, while $69 \%$ of post-operative CD $26^{+} / \mathrm{CD}^{2} 26^{-}$CTC-positive patients experienced cancer recurrence, with a test accuracy of $88.8 \%$. By contrast, post-operative $\mathrm{CD}^{2} 6^{+} / \mathrm{CD} 326^{-} \mathrm{CTC}$-negative patients showed an increase in the three-year progression-free survival rate of $86 \%$, along with a reduced risk of tumor relapse of $>90 \%$. In conclusion, $\mathrm{CD}^{2} 6^{+} / \mathrm{CD} 326^{-} \mathrm{CTC}^{-}$are an independent prog-
\end{abstract}

Correspondence to: Dr Marica Gemei, Center for Genetic Engineering, Advanced Biotechnologies, 486 Via Gaetano Salvatore, Naples I-80145, Italy

E-mail: maricagemei@gmail.com

Key words: cluster of differentiation 26, circulating tumor cell, patient management, colorectal cancer, flow cytometry nostic factor for tumor recurrence rate in multivariate analysis, suggesting that their evaluation could be an additional factor for colorectal cancer recurrence risk evaluation in patient management.

\section{Introduction}

Despite advances in the surgical and therapeutic treatment of colorectal cancer patients, $\sim 30-50 \%$ of patients develop tumor relapse and metastases (1). It is known that colonic adenomas and cancerous lesions easily release cells at a percentage rate five times higher than that of the normal mucosa $(2,3)$. Due to the malignant characteristics of a number of the released cancer cells, they can easily enter the blood circulation and migrate to distant organ sites. This cell dissemination has been recently demonstrated to be an early event, even if only weakly present in initial stages of cancer patients $(4,5)$. Circulating tumor cells (CTCs) may not only establish metastases in distant organs, but may also self-seed back to their origin organ, promoting tumor relapse (6). The detection of CTCs has been associated with a poor prognosis and poor survival rate of colorectal cancer patients (7-9). However, a number of problems affect CTC identification and enumeration; each method used for their detection has several drawbacks (10-13). The scarcity of CTCs in peripheral blood samples means that an enrichment step is often required prior to the analysis $(14,15)$, however, all methods used to enrich CTCs from blood samples (i.e., filtration, density gradient separation and magnetic isolation) exhibit a low purity grade (16-18).

Furthermore, major techniques used to identify CTCs (i.e., quantitative polymerase chain reaction and CellSearch system) are too expensive and time consuming to be predominantly used in the clinical routine $(10,19)$. In addition, nucleic acid-based methods are markedly affected by the presence of a huge number of contaminant cells inside peripheral blood samples $(9,12)$, while intact cell analysis by the use of specific markers is defective due to the lack of unambiguous 
specificities $(9,12,14)$; in fact several of the markers expressed by cancer cells are shared by leucocytes. Flow cytometry is a suitable technique to analyze CTCs (19-22), as it allows single cell analysis and permits the researcher to include or exclude doubtful origin populations and suspect objects from the analysis at any time following sample acquisition. The universally recognized markers of CTCs are the epithelial specificities, CD326 (EpCAM) and the cytokeratins $(9,23,24)$, however, recent findings have highlighted the complex nature of cancer cell dissemination, which involves deep cell changes, including the epithelial-to-mesenchymal (EMT) transition (25-30). The types of modifications that occur in the cell in such transitions are not univocally clarified; it has been demonstrated that cells reduce the epithelial characteristics as mesenchymal features appear $(25,26)$, this transition appears to promote cancer cell dissemination (31-33). In addition, it has been reported that intermediate phenotypes are observable in CTCs with the presence of epithelial and mesenchymal markers $(25,33,34)$. The assessment of biologically significant markers is likely to provide more clinically relevant information than simple enumeration (35), therefore, the development of a precise, accurate and reproducible assay to detect the CTC level in the peripheral blood of colorectal cancer patients requires evaluation of the different cancer cell populations that possess the ability to enter the blood circulation. Therefore, the current study selected two markers to explore the CTC populations in the peripheral blood of colorectal cancer patients by flow cytometry. The aim of the study was to investigate the commonly used epithelial specificity, CD326/EpCAM, and the metastatic colon cancer cell marker, CD26/DPPIV (36-38).

\section{Materials and methods}

Patients. Patients observed between September 2009 and August 2012 at the Second University of Naples School of Medicine (Naples, Italy) with histologically confirmed colorectal adenocarcinoma were considered eligible for this study. Patients meeting the Amsterdam II criteria (39) for hereditary non-polyposis colorectal cancer syndrome or with carcinomas associated with inflammatory bowel disease were excluded from the study. In total, 80 patients, consisting of 48 colon and 32 rectal cancer patients, were included in the study. In addition, 25 healthy subjects served as a control. Informed consent was obtained for each patient or healthy volunteer. According to the pre-operative staging utilizing echo endoscopy and pelvic magnetic resonance imaging, 14 (43.8\%) rectal cancer patients underwent pre-operative chemoradiotherapy (CRT) with a 5-fluorouracil- and oxaliplatin-based regimen and a total radiation dose of $45 \mathrm{~Gy}$, followed by surgery at approximately six to eight weeks following completion of the CRT. Furthermore, $72(90.0 \%)$ patients, including 14 with liver-limited metastatic tumors, underwent potentially curative resection ( $\mathrm{R} 0$ resection), defined as the removal of all of the macroscopic tumoral masses, the absence of microscopic residual tumor, histology-negative resection margins and negative peritoneal cytology (40). In the remaining eight patients, including six patients with distant metastases, the primary tumor was resected, however, the surgery was determined to be non-curative due to local or distant diffusion.
Follow-up. All surgeries were successful and without perioperative mortality. All patients were discharged from the hospital and underwent adjuvant chemotherapy if appropriate. In the rectal cancer cases, adjuvant chemotherapy was performed for pT3 tumors, as well as in the patients treated with neoadjuvant CRT, regardless of post-operative pathological staging (41). Follow-up included a physical examination and carcinoembryonic antigen (CEA) serum level analysis every three months for the first two years, colonoscopy at the one year mark and liver ultrasonography every six months for two years. Chest/abdominal/pelvic computed tomography (CT) scans were performed annually; those patients undergoing liver resection entered a more strict follow-up, including liver ultrasonography every three months and CT scan every six months. In cases where recurrence was suspected, patients were subjected to further diagnostic methods always complemented by routine histopathological examination of a biopsy specimen. In total, 18 of the selected patients experienced cancer relapse.

The following clinicopathological parameters were recorded: Age, gender, tumor site (right and left colon, and rectum), serum CEA levels, performance status according to the Eastern Cooperative Oncology Group scale (39), neoadjuvant CRT, post-operative chemotherapy and complication rate, tumor size, tumor-node-metastasis staging system (42) and Dukes' stage, number of harvested nodes and positive nodes, lymph node ratio (LNR; the ratio between positive nodes and resected nodes), histological differentiation (well, moderate or poor), oncological radicality, recurrence and progression-free survival (PFS) rates.

No patient was lost to follow-up, which was completed by February 28, 2012. All patients provided written informed consent and the study was approved by the Division of Surgical Oncology, Department of Anesthesiological, Surgical and Emergency Sciences of the Second University of Naples School of Medicine (Naples, Italy).

Endpoints. Primary endpoints were the actual capacity of the method to evaluate the levels of $\mathrm{CD} 26^{+} / \mathrm{CD} 326^{-}$cells in the peripheral blood, post-operative modifications of these levels and their correlations with outcome. PFS rate was used to investigate the correlation between the blood levels of CD26 $/ \mathrm{CD} 326^{-}$cells and tumor recurrence. Finally, the independent significance of CD $26^{+} / \mathrm{CD} 326^{-}$cells in predicting cancer relapse was evaluated by multivariate analysis. Secondary endpoints were the correlation between the blood levels of CD26 $/ \mathrm{CD} 326^{-}$cells and other prognostic factors, particularly tumor radical resection, pre-operative therapy and tumor stage.

Statistical analysis. Statistical analysis was performed using the SPSS statistical package (SPSS Inc., Chicago, IL, USA) integrated by MedCalc ${ }^{\circledR}$ software, version 9.4.2.0 (MedCalc, Mariakerke, Belgium). In all analyses, the significance level was specified as $\mathrm{P}<0.05$. Data are presented as the mean \pm standard deviation, range and median values. The equality of group means and comparisons between proportions were analyzed using a paired Student's t-test and $\chi^{2}$ test, respectively.

Linear regression was used to investigate the correlations among different blood levels of $\mathrm{CD} 26^{+} / \mathrm{CD} 326^{-}$cells and other prognostic factors. Univariate analysis associated with PFS was limited to radically resected patients and determined by log-rank 
test (Mantel-Cox). Curves were plotted using the Kaplan-Meier method, providing the P-value and hazard ratio with a 95\% confidence interval (CI). The independent significance of the prognostic variables was determined by multivariate analysis, using Cox's proportional hazards model.

Peripheral blood sample treatment. For each patient and healthy control in the study, $7.5 \mathrm{ml}$ of peripheral blood was harvested and diluted 1:2 with phosphate-buffered saline (PBS; Sigma-Aldrich, St. Louis, MO, USA) without $\mathrm{Ca}^{2+} / \mathrm{Mg}^{2+}$. Mononucleated cells were recovered from peripheral blood samples by centrifugation using a Ficoll Histopaque (Sigma-Aldrich) for $30 \mathrm{~min}$ at $320 \mathrm{x} \mathrm{g}$. The mononuclear cell ring was isolated and washed twice with PBS at $320 \mathrm{x} \mathrm{g}$ for $3 \mathrm{~min}$. All recovered cells were stained with the appropriate amount of mouse anti-human monoclonal anti-CD326 PerCP-Cy5.5, anti-CD45-APC-Cy7 and anti-CD26-FITC antibodies (BD Bioscience, San Jose, CA, USA). For each patient, a pre- and post-operative peripheral blood sample $(7.5 \mathrm{ml}$ each) was analyzed. The post-operative sample was obtained one month after the surgical treatment. In addition, 25 samples obtained from the healthy controls were used as control.

\section{Results}

Identification of a CD26 $6^{+} C D 326-C T C$ population and comparison with $C D 326^{+}$CTCs present in colorectal cancer patients. A multiparametric cytometric analysis was used to evaluate the CD $26^{+} / \mathrm{CD} 326^{-}$CTCs present in the peripheral blood samples of the colon cancer patients and healthy controls. The cells were first gated on physical parameters in a dot plot [forward scatter versus side scatter (SSC)] to exclude debris. Subsequently, in a CD45 versus SSC dot plot, the CD $45^{\circ}$ cell population position was identified by discarding all hematopoietic contaminants. Finally, in a CD326 versus CD26 dot plot, 'conventional' CD326 and $\mathrm{CD}^{2} 6^{+} / \mathrm{CD} 326-\mathrm{CTCs}$ were identified (Fig. 1). Furthermore, the expression of three colorectal cancer stem cell markers, CD44, CD66c and CD133, were evaluated $(43,44)$ on $\mathrm{CD}_{32} 6^{+}$and CD26 ${ }^{+} / \mathrm{CD} 326^{-}$cells, observing the consistent expression of CD44 and CD66c along with a substantial negativity for CD133 (data not shown). CD $326^{+}$and $\mathrm{CD} 26^{+} / \mathrm{CD} 326^{-}$cells were identified in the peripheral blood samples of the 25 healthy controls and 80 colorectal cancer (60 non-metastatic and 20 metastatic) patients. Analysis of the healthy controls allowed a cut-off to be defined in order to determine the background level for the analysis. In the healthy subjects, at least one $\mathrm{CD} 326^{+} \mathrm{CTC}$ was counted, however, no CD26/CD326 cells were identified. Therefore, positive patients samples were considered to exhibit $\geq 1 \mathrm{CD}_{2} 26^{+}$and $>0 \mathrm{CD} 26^{+} / \mathrm{CD} 326^{-}$CTCs. CD $326^{+}$tumor cell circulation was found to be a more common event than CD26 ${ }^{+} / \mathrm{CD} 326^{-}$cell spreading; 62 patients were pre-operatively positive for $\mathrm{CD} 326^{+}$cells, 36 of whom were also positive for $\mathrm{CD}^{2} 6^{+} / \mathrm{CD} 326^{-}$cells. Furthermore, the pre-operative blood levels of $\mathrm{CD} 326^{+}$cells in the cancer patients ranged between 0 and 165 (mean, 24.45 \pm 34.92 ; 95\% CI, 12.97-35.92; median, 11.50), while those of the $\mathrm{CD} 26^{+} / \mathrm{CD} 326^{-}$cells ranged between 0 and 24 (mean, 3.97 \pm 6.4 ; 95\% CI, 2.53-5.41; median, 0). CD $326^{+}$cell spreading is likely to be the first event in cancer cell dissemination, since no patients were positive for $\mathrm{CD}^{2} 6^{+} / \mathrm{CD} 326^{-}$cells, but they were positive for

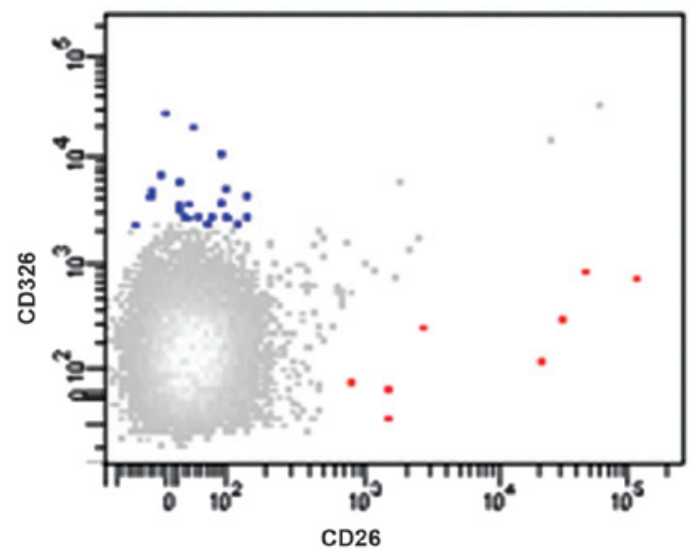

Figure $1 . \mathrm{CD} 36^{+}$and CD26 ${ }^{+} / \mathrm{CD} 326^{-} \mathrm{CTC}^{-}$detection. The CD326 versus CD26 dot plot shows a representative pre-operative sample of peripheral blood in which $\mathrm{CD}_{2} 6^{+}$(blue) and CD26+CD326- (red) CTCs were detected. Cells were identified in the $\mathrm{CD} 45$-negative non-hematopoietic cell population. $\mathrm{CD}$, cluster of differentiation; CTC, circulating tumor cell.

$\mathrm{CD} 326^{+}$cells. Pre-operative CD $326^{+}$cells were identified in $48 \mathrm{M} 0$ and $14 \mathrm{M} 1$ patients. All patients who experienced cancer relapse exhibited pre-operative $\mathrm{CD}_{2} 26^{+}$cells, while $\mathrm{CD} 26^{+}$cells were detected in $26 \mathrm{M} 0$ and $10 \mathrm{M} 1$ patients pre-operatively. All but two patients who experienced cancer recurrence were positive for $\mathrm{CD}^{-} 6^{+} / \mathrm{CD} 326^{-}$cells pre-operatively. In the post-operative analysis, eight M0 and $10 \mathrm{M} 1$ patients were CD $326^{+}$CTC-positive, while $16 \mathrm{M} 0$ and $10 \mathrm{M} 1$ were positive for $\mathrm{CD} 26^{+} / \mathrm{CD} 326^{-}$cells. Post-operative $\mathrm{CD}_{2} 26^{+}$was detected in the $66.6 \%$ of patients who relapsed (12 out of 18 ), while $\mathrm{CD} 26^{+} / \mathrm{CD} 326^{-}$cells predicted all relapses. No pre-operative $\mathrm{CD}_{2} 26^{+} \mathrm{CTC}$-negative patients became positive post-operatively, while six patients who were $\mathrm{CD} 26^{+} / \mathrm{CD} 326^{-}$CTC-negative pre-operatively became positive post-operatively; two experienced cancer relapse. The clinical relevance of $\mathrm{CD} 326^{+} \mathrm{CTCs}$ was analyzed in a previous study (45), therefore, now only $\mathrm{CD}^{2} 6^{+} / \mathrm{CD} 326^{-}$cells are considered to correlate with the clinical outcome of colorectal cancer patients.

Pre-operative analysis of $C D 26^{+} / C D 326^{-}$CTCs. In Table I, the correlations between the blood levels of $\mathrm{CD}^{-} 6^{+} / \mathrm{CD} 326^{-}$cells and other clinicopathological variables are shown. High pre-operative levels of $\mathrm{CD} 26^{+} / \mathrm{CD} 326^{-}$cells tended to be more frequent in patients with advanced Dukes' stages, and were significantly associated with the requirement for adjuvant chemotherapy, undifferentiated tumors, and poor recurrence and survival rates. Neoadjuvant CRT did not affect the blood levels of $\mathrm{CD} 26^{+} / \mathrm{CD} 326^{-}$cells. Linear regression showed that the blood levels of $\mathrm{CD} 26^{+} / \mathrm{CD} 326^{-}$cells were increased in younger patients with rectal cancer, high CEA levels, advanced Dukes' stages and undifferentiated tumors. Relapsing and non-surviving patients showed the highest pre-operative levels of $\mathrm{CD}^{2} 6^{+} / \mathrm{CD} 326^{-}$cells $\left(\mathrm{r}=0.475, \mathrm{P}<0.001\right.$ for $\mathrm{CD} 26^{+}$; and $\mathrm{r}=0.4237, \mathrm{P}<0.001$ for $\mathrm{CD}^{2} 6^{-}$).

Post-operative evaluation of CD26 $/ C D 326^{-}$CTCs. One month after surgery, the blood levels of $\mathrm{CD} 26^{+} / \mathrm{CD} 326^{-}$cell levels had dropped significantly (mean, 1.20 2.36 ; $95 \%$ CI, 0.67-1.72; range, 0 to 11 ; median, 0 ; $\mathrm{P}<0.0001$ ) compared 
Table I. Clinicopathological characteristics of the series, and correlations between pre-operative blood levels of CD26 ${ }^{+} / \mathrm{CD}^{2} 26^{-}$cells and other factors.

\begin{tabular}{|c|c|c|c|}
\hline Variables & $\mathrm{CD} 26^{+} / \mathrm{CD} 326^{-}$-negative $(\mathrm{n}=44)$ & $\mathrm{CD} 26^{+} / \mathrm{CD} 326^{-}$-positive $(\mathrm{n}=36)$ & P-value \\
\hline \multicolumn{4}{|l|}{ Age, years ${ }^{b}$} \\
\hline$\leq 66$ & 22 & 20 & \multirow[t]{2}{*}{0.7871} \\
\hline$>66$ & 22 & 16 & \\
\hline \multicolumn{4}{|l|}{ Gender } \\
\hline Male & 30 & 22 & \multirow[t]{2}{*}{0.6715} \\
\hline Female & 14 & 14 & \\
\hline \multicolumn{4}{|l|}{ Tumor site } \\
\hline Right colon & 6 & 8 & \multirow[t]{3}{*}{0.2936} \\
\hline Left colon & 22 & 12 & \\
\hline Rectum & 16 & 16 & \\
\hline \multicolumn{4}{|l|}{ Serum CEA levels, $\mathrm{ng} / \mathrm{ml}^{\mathrm{c}}$} \\
\hline$\leq 3.5$ & 30 & 18 & \multirow[t]{2}{*}{0.1550} \\
\hline$>3.5$ & 14 & 18 & \\
\hline \multicolumn{4}{|l|}{ Performance status ${ }^{\mathrm{d}}$} \\
\hline 0 & 22 & 18 & \multirow[t]{3}{*}{0.1857} \\
\hline 1 & 14 & 16 & \\
\hline 2 & 8 & 2 & \\
\hline \multicolumn{4}{|l|}{ Neoadjuvant $\mathrm{CRT}^{\mathrm{e}}$} \\
\hline No & 10 & 8 & \multirow[t]{2}{*}{0.7216} \\
\hline Yes & 6 & 8 & \\
\hline \multicolumn{4}{|l|}{ Adjuvant chemotherapy } \\
\hline No & 16 & 4 & \multirow[t]{2}{*}{0.0195} \\
\hline Yes & 28 & 32 & \\
\hline \multicolumn{4}{|c|}{ Post-operative complications } \\
\hline No & 44 & 32 & \multirow[t]{2}{*}{0.0796} \\
\hline Yes & 0 & 4 & \\
\hline \multicolumn{4}{|l|}{ Tumor size, $\mathrm{cm}^{\mathrm{b}}$} \\
\hline$\leq 4$ & 24 & 22 & \multirow[t]{2}{*}{0.7161} \\
\hline$>4$ & 20 & 14 & \\
\hline \multicolumn{4}{|l|}{ pT stage } \\
\hline 1 & 4 & 2 & \multirow[t]{4}{*}{0.5343} \\
\hline 2 & 12 & 6 & \\
\hline 3 & 16 & 18 & \\
\hline 4 & 12 & 10 & \\
\hline \multicolumn{4}{|l|}{ pN stage } \\
\hline Lymph node-negative & 24 & 14 & \multirow[t]{2}{*}{0.2420} \\
\hline Lymph node-positive & 20 & 22 & \\
\hline \multicolumn{4}{|l|}{ pM stage } \\
\hline M0 & 34 & 26 & \multirow[t]{2}{*}{0.7952} \\
\hline M1 & 10 & 10 & \\
\hline Dukes' stage & & & \\
\hline A & 16 & 4 & 0.0676 \\
\hline B & 8 & 8 & \\
\hline $\mathrm{C}$ & 10 & 14 & \\
\hline $\mathrm{D}$ & 10 & 10 & \\
\hline
\end{tabular}


Table I. Continued.

\begin{tabular}{|c|c|c|c|}
\hline Variables & $\mathrm{CD}^{2} 6^{+} / \mathrm{CD} 326^{-}$-negative $(\mathrm{n}=44)$ & CD26 ${ }^{+} / \mathrm{CD} 36^{-}-$positive $(\mathrm{n}=36)$ & P-value ${ }^{a}$ \\
\hline \multicolumn{4}{|c|}{ Histological differentiation } \\
\hline Well & 26 & 12 & 0.0018 \\
\hline Moderate & 18 & 16 & \\
\hline Poor & 0 & 8 & \\
\hline \multicolumn{4}{|c|}{ Radical resection } \\
\hline Yes & 38 & 34 & 0.4099 \\
\hline No & 6 & 2 & \\
\hline \multicolumn{4}{|c|}{ Tumor recurrence } \\
\hline No & 42 & 20 & 0.0001 \\
\hline Yes & 2 & 16 & \\
\hline \multicolumn{4}{|l|}{ Survival } \\
\hline Yes & 42 & 28 & 0.0001 \\
\hline No & 2 & 8 & \\
\hline
\end{tabular}

${ }^{\mathrm{a}} \chi^{2}$ test; ${ }^{\mathrm{b}}$ median value; ${ }^{\mathrm{c} n o r m a l}$ value in healthy subjects; ${ }^{\mathrm{d}}$ performance status according to the Eastern Cooperative Oncology Group scale; only rectal cancer patients. CEA, carcinoembryonic antigen; CRT, chemoradiotherapy; CD, cluster of differentiation.

with the pre-operative levels. Among the pre-operative CD26 ${ }^{+} / \mathrm{CD} 326^{-}$CTC-negative patients, 38 remained negative and six $(16 \%)$ showed post-operative $\mathrm{CD}^{2} 6^{+} / \mathrm{CD} 326^{-}$positivity; in the pre-operative $\mathrm{CD}^{2} 6^{+} / \mathrm{CD} 326^{-} \mathrm{CTC}^{-}$positive group, 14 (38.9\%) patients were post-operatively CD $26^{+} / \mathrm{CD} 326^{-}$CTC-negative and 22 remained positive. Notably, among the 72 patients undergoing potentially curative surgery, $26(36.1 \%)$ continued to show elevated post-operative blood levels of $\mathrm{CD}^{2} 6^{+} / \mathrm{CD} 326^{-}$cells; by contrast, from the eight patients undergoing non-radical surgery, six $(75.0 \%)$ showed normalized levels of CD26 $6^{+} \mathrm{CD} 326^{-}$cells, and two were $\mathrm{CD}^{2} 6^{+} / \mathrm{CD} 326^{-} \mathrm{CTC}$-positive. This suggested that post-operative blood levels of $\mathrm{CD}^{2} 6^{+} / \mathrm{CD} 326^{-}$cells do not correlate with surgical and/or pathological radicality $(\mathrm{r}=0.1136$, $\mathrm{P}=0.3162$ ). Therefore, cancers that have supposedly been radically resected may continue to spread through the blood.

Analysis associated with outcome. The mean follow-up time was 23 \pm 10 months (95\% CI, 21-25; range, 3-42; median, 25). In this time period, 10 patients succumbed to cancer; the oneto three-year overall survival rates were $96.3,85.8$ and $82.2 \%$, respectively. All but two patients who succumbed showed high pre- and post-operative levels of $\mathrm{CD}^{2} 6^{+} / \mathrm{CD} 326^{-}$cells. Among the 72 patients undergoing potentially curative surgery, $18(25 \%)$ patients showed tumor recurrence (mean, 16 \pm 8 ; 95\% CI, 12-20; range, 4-34; median, 15 months). The one- to three-year overall PFS rates were 90.0, 77.2 and $63.3 \%$, respectively. No tumor recurrence was experienced after 36 months. High pre-operative blood levels of CD26 ${ }^{+} / \mathrm{CD} 326^{-}$cells correctly predicted tumor relapse in $44.4 \%$ of the cases (Fig. 2A); by contrast, patients with normal pre-operative blood levels of CD26 ${ }^{+} / \mathrm{CD} 326^{-}$cells developed recurrence in only $5 \%$ of cases (test accuracy, $72.5 \%$ ). The performance of the test of post-operative blood levels of CD26 ${ }^{+} / \mathrm{CD} 326^{-}$cells in predicting tumor recurrence was even more impressive, with a test accuracy of $88.8 \%$ (Fig. 2B).
Among the 26 patients showing high post-operative blood levels of $\mathrm{CD}^{2} 6^{+} / \mathrm{CD} 326^{-}$cells, 18 (69.2\%) relapsed, while no tumor recurrence was observed among the 46 patients with normal post-operative blood levels of $\mathrm{CD}^{2} 6^{+} / \mathrm{CD}^{2} 26^{-}$cells. A younger age, elevated serum CEA level, adjuvant chemotherapy, advanced pT stage, lymph node-positive status, distant metastases, advanced Dukes' stage and limited lymph node yield were shown to significantly correlate with an increased recurrence rate. Poor performance status and high LNR were marginally associated with a poor outcome. Pre- and post-operative blood levels of $\mathrm{CD} 26^{+} / \mathrm{CD} 326^{-}$cells were found to markedly correlate with the tumor relapse rate (Table II). Pre- and post-operative CD26 ${ }^{+} / \mathrm{CD} 326^{-}$CTC-negative patients showed an increase in the three-year PFS rate of 42 and $86 \%$, respectively, with a reduction of the relative risk of tumor relapse to $>90 \%$ (Fig. 3). Together with the presence of distant metastases and advanced Dukes' stage, pre- and post-operative high blood levels of CD26 $/ \mathrm{CD} 326^{-}$cells were found to be independent prognostic factors that correlated with an increased tumor recurrence rate on multivariate analysis (Table III). The statistical power of the described variables covered the prognostic significance of factors known to affect long-term outcome, including $\mathrm{pT}$ and $\mathrm{pN}$ status. Pre- and post-operative high blood levels of CD26 ${ }^{+} / \mathrm{CD} 326^{-}$cells conditioned a probability of tumor relapse that was, respectively, 11 and 18 times higher than that observed in patients who had no detectable blood levels of $\mathrm{CD} 26^{+} / \mathrm{CD} 326^{-}$cells.

\section{Discussion}

One of the most important drawbacks for CTC detection and its usefulness in the clinic is the lack of specific markers of biologically important subsets of CTCs $(19,23,35,46,47)$. CD326 has been confirmed to be adequate to isolate CTCs $(18,23)$, even if its use has been recently questioned, 
Table II. Univariate analysis associated with PFS in 72 patients with colorectal cancer who underwent potentially curative surgery.

\begin{tabular}{|c|c|c|c|c|c|}
\hline Variables & $\mathrm{n}$ & $\begin{array}{l}\text { 42-month } \\
\text { PFS, } \%\end{array}$ & $\begin{array}{l}\text { Hazard } \\
\text { ratio }\end{array}$ & $\begin{array}{c}\text { Hazard } \\
\text { ratio }(95 \% \mathrm{CI})\end{array}$ & P-value \\
\hline Age $\leq 67 />67$, years $^{a}$ & $40 / 32$ & $52 / 79$ & 2.99 & $1.04-6.68$ & 0.0411 \\
\hline Gender M/F & $46 / 26$ & $70 / 52$ & 0.66 & $0.24-1.73$ & 0.3929 \\
\hline Tumor site & & & & & 0.6842 \\
\hline Right colon & 14 & 61 & & & \\
\hline Left colon & 28 & 57 & & & \\
\hline Rectum & 30 & 67 & & & \\
\hline Serum CEA levels, $\mathrm{ng} / \mathrm{ml}^{\mathrm{b}}$ & & & & & 0.0054 \\
\hline$\leq 3.5$ & 46 & 84 & 0.27 & $0.09-0.66$ & \\
\hline$>3.5$ & 26 & 36 & & & \\
\hline Performance status $0 / 1 / 2^{c}$ & $36 / 28 / 8$ & $49 / 83 / 100$ & & & 0.0917 \\
\hline Neoadjuvant CRT, no/yes & $60 / 12$ & $66 / 51$ & 0.67 & $0.18-2.26$ & 0.4910 \\
\hline Adjuvant chemotherapy, no/yes & $20 / 52$ & $100 / 54$ & 0.00 & $0.08-0.69$ & 0.0084 \\
\hline Post-operative complications, no/yes & $68 / 4$ & $64 / 37$ & 0.32 & $0.01-1.59$ & 0.1149 \\
\hline Tumor size $\leq 4 />4, \mathrm{~cm}^{\mathrm{a}}$ & $46 / 26$ & $60 / 71$ & 1.00 & $0.37-2.68$ & 0.9912 \\
\hline pT stage & & & & & 0.1588 \\
\hline 1 & 6 & 100 & & & \\
\hline 2 & 18 & 82 & & & \\
\hline 3 & 32 & 56 & & & \\
\hline 4 & 16 & 68 & & & \\
\hline $1-2 / 3-4$ & $24 / 48$ & $86 / 55$ & 0.24 & $0.13-0.96$ & 0.0428 \\
\hline pN stage, negative/positive & $38 / 34$ & $85 / 45$ & 0.22 & $0.10-0.65$ & 0.0043 \\
\hline pM stage, M0/M1 & $58 / 14$ & $77 / 17$ & 0.25 & $0.03-0.47$ & 0.0017 \\
\hline Dukes' stage & & & & & 0.0012 \\
\hline A & 20 & 100 & & & \\
\hline $\mathrm{B}$ & 16 & 85 & & & \\
\hline $\mathrm{C}$ & 22 & 56 & & & \\
\hline $\mathrm{D}$ & 14 & 17 & & & \\
\hline A-B/C-D & $36 / 36$ & $93 / 54$ & 0.11 & $0.07-0.46$ & 0.0008 \\
\hline Harvested Nodes, $\mathrm{n}^{\mathrm{a}}$ & & & & & 0.0391 \\
\hline$<15$ & 34 & 42 & 2.67 & $1.05-6.90$ & \\
\hline$>15$ & 38 & 78 & & & \\
\hline Lymph Node Ratio ${ }^{d}$ & & & & & 0.0720 \\
\hline$<0.1818$ & 14 & 79 & 0.28 & $0.12-1.09$ & \\
\hline$>0.1818$ & 20 & 31 & & & \\
\hline Histological differentiation & & & & & 0.3026 \\
\hline Well & 34 & 85 & & & \\
\hline Moderate & 32 & 66 & & & \\
\hline Poor & 6 & 56 & & & \\
\hline Pre-operative CD26 ${ }^{+} / \mathrm{CD} 326^{-}$cells & & & & & $<0.0001$ \\
\hline Negative & 38 & 84 & 0.08 & $0.05-0.35$ & \\
\hline Positive & 34 & 42 & & & \\
\hline
\end{tabular}


Table II. Continued.

\begin{tabular}{|c|c|c|c|c|c|}
\hline Variables & $\mathrm{n}$ & $\begin{array}{l}\text { 42-month } \\
\text { PFS, } \%\end{array}$ & $\begin{array}{l}\text { Hazard } \\
\text { ratio }\end{array}$ & $\begin{array}{c}\text { Hazard } \\
\text { ratio }(95 \% \mathrm{CI})\end{array}$ & P-value \\
\hline \multicolumn{6}{|c|}{ Post-operative $\mathrm{CD}^{2} 6^{+} / \mathrm{CD} 326^{-}$cells } \\
\hline Negative & 46 & 100 & 0.00 & $0.00-0.07$ & $<0.0001$ \\
\hline Positive & 26 & 14 & & & \\
\hline
\end{tabular}

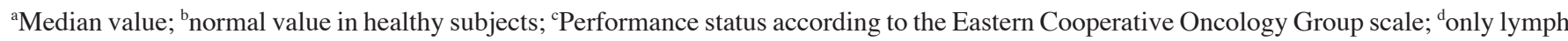
node-node positive patients and according to the cut-off value. PFS, progression-free survival; CI, confidence interval; M, male; F, female; CEA, carcinoembryonic antigen; CRT, chemoradiotherapy.

Table III. Multivariate analysis associated with progression-free survival in 72 patients with colorectal cancer who underwent potentially curative surgery.

\begin{tabular}{|c|c|c|c|c|c|}
\hline Variables & Coefficient & Standard error & Hazard ratio & Hazard ratio $(95 \% \mathrm{CI})$ & P-value \\
\hline Younger age & 1.1577 & 1.6664 & 3.18 & $0.12-82.04$ & 0.4872 \\
\hline Elevated serum CEA levels & 0.6012 & 0.8281 & 1.82 & $0.36-9.17$ & 0.4678 \\
\hline Adjuvant chemotherapy & 0.8637 & 0.5977 & 2.37 & $0.73-7.60$ & 0.1484 \\
\hline Advanced pT stage & 1.1986 & 1.1068 & 3.31 & $0.38-28.69$ & 0.2788 \\
\hline Lymph node-positive & 1.3721 & 1.5026 & 3.94 & $0.21-73.85$ & 0.3612 \\
\hline Distant metastases & 2.1588 & 0.6452 & 8.66 & $2.46-30.47$ & 0.0008 \\
\hline Advanced Dukes' stage & 1.8925 & 0.6936 & 6.63 & $1.71-25.66$ & 0.0063 \\
\hline$<15$ harvested nodes & 1.2570 & 1.4078 & 3.51 & $0.22-54.71$ & 0.3719 \\
\hline $\begin{array}{l}\text { High pre-operative levels of } \\
\text { CD26 } \\
+ \text { CD } 326^{-} \text {cells }\end{array}$ & 2.4530 & 0.6506 & 11.62 & $3.26-41.33$ & 0.0001 \\
\hline $\begin{array}{l}\text { High post-operative levels of } \\
\mathrm{CD} 26^{+} / \mathrm{CD} 326^{-} \text {cells }\end{array}$ & 2.8901 & 0.7769 & 17.99 & $3.92-82.50$ & 0.0001 \\
\hline
\end{tabular}

Multivariate analysis was performed including variables with significant value on univariate analysis, by Cox's proportional hazards model. CI, confidence interval; CEA, carcinoembryonic antigen.

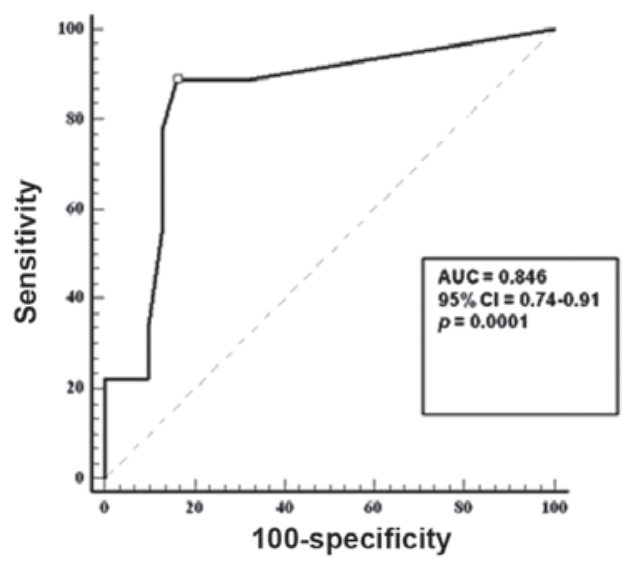

Sensitivity $88.9 \%$ :

Positive Predictive Value $44.4 \%$

Negative Predictive Value $95.5 \%$

Accuracy $72.5 \%$

AUC indicates Area under the ROC curve with its $95 \%$ confidence interval $(\mathrm{Cl})$

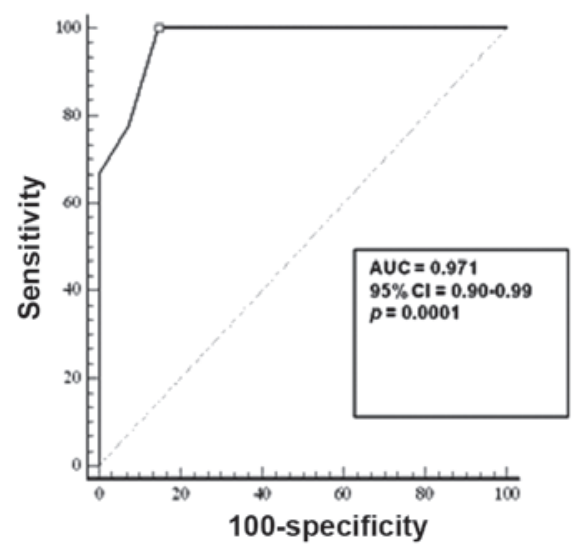

Sensitivity $100 \%$ :

Positive Predictive Value $69.2 \%$

Negative Predictive Value $100 \%$

Accuracy $88.8 \%$

AUC indicates Area under the ROC curve with its $95 \%$ confidence interval (Cl)

Figure 2. ROC curve analysis at different values of (A) pre- and (B) post-operative blood levels of $\mathrm{CD}_{2} 6^{+} / \mathrm{CD} 326^{-}$cells is shown. The value of 0 cells for $7.5 \mathrm{ml}$ of peripheral blood is indicated with a square sign and corresponds with the highest accuracy (minimal false-negative and false-positive results). ROC, receiver operating characteristic; AUC, area under curve; $\mathrm{CI}$, confidence interval; $\mathrm{CD}$, cluster of differentiation. 

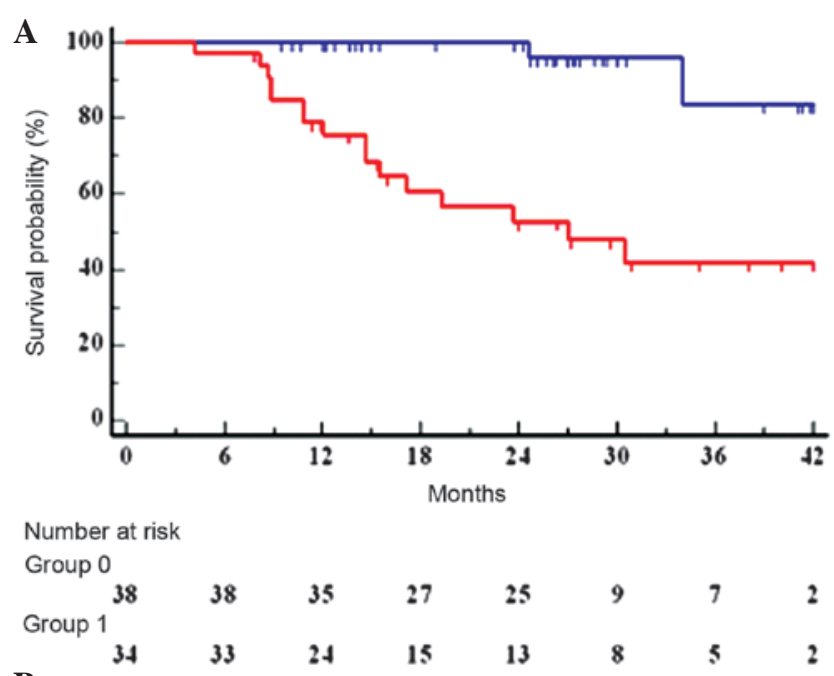

B

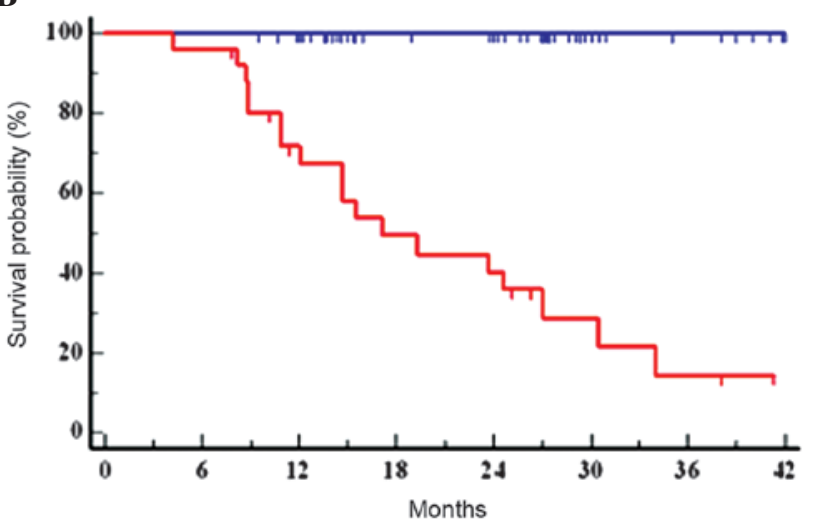

Number at risk

Group 0

$\begin{array}{rrrrrrrr}46 & 46 & 43 & 31 & 29 & 13 & 10 & 4 \\ \text { Group 1 } & 25 & 16 & 11 & 9 & 4 & 2 & 0\end{array}$

Figure 3. Three-year progression-free survival rate in the 72 colorectal cancer patients who underwent potentially curative surgery according to (A) pre- and (B) post-operative blood levels of CD $26^{+} / \mathrm{CD}_{2} 26^{-}$cells. Group $0, \mathrm{CD}^{2} 6^{+} / \mathrm{CD}^{-} 26^{-}$cell-negative patients and group $1, \mathrm{CD} 26^{+} / \mathrm{CD} 326^{-}$cell-positive patients.

as circulating $\mathrm{CD} 36^{+}$cells are also detected in patients with benign diseases of the colon (21). Furthermore, in colon cancer, EMT and the loss of epithelial specificities has been observed in cells that are prone to entering the blood circulation $(26,27,30,31)$. The present study analyzed the expression of the epithelial marker, CD326/EpCAM, and the metastatic cancer cell marker, CD26/DPPIV (36) in CTCs obtained from colorectal cancer patients. The presence of two subsets of CTCs were demonstrated, one expressing CD326 and one expressing CD26, but each CD326-negative. CD26-positive cells from colon cancer exhibit metastatic abilities (36), and the results from the current study demonstrated, for the first time, their presence in the blood circulation of colorectal cancer patients and the correlation with patient prognosis for cancer recurrence. Furthermore, the expression of CD44, CD133 and CD66c protein expression was analyzed on the surface of the CTCs (data not shown), as they are described as colon cancer stem cell markers $(43,44)$, and it is likely that these cells are more prone to entering the blood circulation to disseminate in the whole body and generate metastasis (27). The pheno- typic analysis revealed that, in contrast to CD133, CD44, CD66c and CD26, are reliable markers of CTCs in colon cancer patients (data not shown). Notably, CD44 and CD66c showed functional properties in colon cancer cells, however, by contrast, the functional importance of CD133 appeared to be marginal (48-50). These results suggested that stem-like tumor initiating-cells are responsible for cancer spread and recurrence. In this study, relapsing patients showed a positivity for $\mathrm{CD}_{2} 26^{+}$and $\mathrm{CD} 26^{+} / \mathrm{CD} 326^{-} \mathrm{CTC}$ s even when the primary cancer had a low pathological grade, suggesting that CTCs can identify high-risk colorectal cancer patients at early stages. Notably, the spread of CD $326^{+}$cancer cells into the blood circulation is a common event and $77.5 \%$ of all analyzed patients exhibited these cells in their peripheral blood pre-operatively, while $45.0 \%$ exhibited CD $26^{+} / \mathrm{CD} 326^{-}$cells. Notably, only $50.0 \%$ of metastatic patients had $\mathrm{CD} 26^{+} / \mathrm{CD} 326^{-}$cells in their bloodstream. This suggested that cancer cell spreading is a changeable process, which could be enhanced to favor cancer cell dissemination while being reduced once cancer cells have been reseeded in distant organs. As predicted, patients with high-grade and advanced stage cancers showed a higher positivity for $\mathrm{CD}^{2} 6^{+} / \mathrm{CD} 326^{-}$CTCs. Furthermore, relapsing and non-surviving patients had the highest positivity observed. CD26 ${ }^{+} / \mathrm{CD}^{-} 2^{-}$cell number was increased in young patients, suggesting that the spread of the cancer cells is slowed by increasing age. Curative surgery was confirmed to be fundamental for $\mathrm{CD}^{2} 6^{+} / \mathrm{CD} 326^{-}$CTC reduction, even if a number of pre-operative $\mathrm{CD}^{2} 6^{+} / \mathrm{CD} 326^{-} \mathrm{CTC}^{-}$-positive patients continued to exhibit CTCs following surgery. This demonstrated that CTCs have the ability to survive for a long time, however, advanced studies are required to assess if CTCs survive in the bloodstream or in a niche, such as the bone marrow $(51,52)$. Post-operatively, 22 patients $(61.1 \%)$ remained positive for CD26 ${ }^{+} / \mathrm{CD}^{2} 26^{-} \mathrm{CTCs}$, while six patients (16\%) who were pre-operatively negative became positive. The limited effect of surgery in the elimination of these CTCs suggested that CD26 ${ }^{+} / \mathrm{CD} 326^{-}$cells function as the root of the tumor and are probably induced to circulate for tumor growth or expansion. Overall, the results of the current study suggested that CD26 ${ }^{+} / \mathrm{CD} 326^{-}$cells are likely to be responsible for metastatic processes and cancer recurrence. Therefore, their identification may have clinical relevance in the evaluation of risk assessment for patients. Patients with pre- and/or post-operative CD26 ${ }^{+} / \mathrm{CD} 326^{-}$CTCs had an 11- to 18-times higher risk of cancer recurrence. Further studies are required to investigate the biological function of this cancer cell subset, while a refined assay for their detection may provide an incentive to their use in the clinical management of colorectal cancer patients.

\section{References}

1. Winawer S, Fletcher R, Rex D, et al: Colorectal cancer screening and surveillance: clinical guidelines and rationale - Update based on new evidence. Gastroenterology 124: 544-560, 2003.

2. Loktionov A, O'Neill IK, Silvester KR, et al: Quantitation of DNA from exfoliated colonocytes isolated from human stool surface as a novel noninvasive screening test for colorectal cancer. Clin Cancer Res 4: 337-342, 1998.

3. Davies RJ, Miller R and Coleman N: Screening for colorectal cancer using stool. Discov Med 5: 175-179, 2005.

4. Lin H, Balic M, Zheng S, Datar R and Cote RJ: Disseminated and circulating tumor cells: Role in effective cancer management. Crit Rev Oncol Hematol 77: 1-11, 2011. 
5. Eyles J, Puaux AL, Wang X, et al: Tumor cells disseminate early, but immunosurveillance limits metastatic outgrowth, in a mouse model of melanoma. J Clin Invest 120: 2030-2039, 2010.

6. Kim MY, Oskarsson T, Acharyya S, et al: Tumor self-seeding by circulating cancer cells. Cell 139: 1315-1326, 2009.

7. Sastre J, Maestro ML, Puente J, et al: Circulating tumor cells in colorectal cancer: correlation with clinical and pathological variables. Ann Oncol 19: 935-938, 2008.

8. Iinuma $\mathrm{H}$, Watanabe $\mathrm{T}$, Mimori $\mathrm{K}$, et al: Clinical significance of circulating tumor cells, including cancer stem-like cells, in peripheral blood for recurrence and prognosis in patients with Dukes' stage B and C colorectal cancer. J Clin Oncol 29: 1547-1555, 2011.

9. Wong SC, Chan CM, Ma BB, et al: Clinical significance of cytokeratin 20-positive circulating tumor cells detected by a refined immunomagnetic enrichment assay in colorectal cancer patients. Clin Cancer Res 15: 1005-1012, 2009.

10. Chiappini F: Circulating tumor cells measurements in hepatocellular carcinoma. Int J Hepatol 2012: 684802, 2012.

11. Allan AL and Keeney M: Circulating tumor cell analysis: technical and statistical considerations for application to the clinic. J Oncol 2010: 426218, 2010.

12. Attard $\mathrm{G}$ and de Bono JS: Utilizing circulating tumor cells: challenges and pitfalls. Curr Opin Genet Dev 21: 50-58, 2011

13. Lianidou ES and Markou A: Circulating tumor cells in breas cancer: detection systems, molecular characterization, and future challenges. Clin Chem 57: 1242-1255, 2011.

14. Sun YF, Yang XR, Zhou J, et al: Circulating tumor cells: advances in detection methods, biological issues, and clinical relevance. J Cancer Res Clin Oncol 137: 1151-1173, 2011.

15. Alunni-Fabbroni M and Sandri MT: Circulating tumour cells in clinical practice: Methods of detection and possible characterization. Methods 50: 289-297, 2010.

16. Königsberg R, Obermayr E, Bises G, et al: Detection of EpCAM positive and negative circulating tumor cells in metastatic breast cancer patients. Acta Oncol 50: 700-710, 2011.

17. Panteleakou Z, Lembessis P, Sourla A, et al: Detection of circulating tumor cells in prostate cancer patients: methodological pitfalls and clinical relevance. Mol Med 15: 101-114, 2009

18. Yu M, Stott S, Toner M, Maheswaran S and Haber DA Circulating tumor cells: approaches to isolation and characterization. J Cell Biol 192: 373-382, 2011.

19. Parkinson DR, Dracopoli N, Petty BG, et al: Considerations in the development of circulating tumor cell technology for clinical use. J Transl Med 10: 138, 2012

20. Hu Y, Fan L, Zheng J, et al: Detection of circulating tumor cells in breast cancer patients utilizing multiparameter flow cytometry and assessment of the prognosis of patients in different CTCs levels. Cytometry A 77: 213-219, 2010.

21. Allan AL, Vantyghem SA, Tuck AB, et al: Detection and quantification of circulating tumor cells in mouse models of human breast cancer using immunomagnetic enrichment and multiparameter flow cytometry. Cytometry A 65: 4-14, 2005.

22. Takao $\mathrm{M}$ and Takeda K: Enumeration, characterization, and collection of intact circulating tumor cells by cross contamination-free flow cytometry. Cytometry A 79: 107-117, 2011.

23. van de Stolpe A, Pantel K, Sleijfer S, Terstappen LW and den Toonder JM: Circulating tumor cell isolation and diagnostics: toward routine clinical use. Cancer Res 71: 5955-5960 2011.

24. Paterlini-Brechot $\mathrm{P}$ and Benali NL: Circulating tumor cells (CTC) detection: clinical impact and future directions. Cancer Lett 253: 180-204, 2007.

25. Armstrong AJ, Marengo MS, Oltean S, et al: Circulating tumor cells from patients with advanced prostate and breast cancer display both epithelial and mesenchymal markers. Mol Cancer Res 9: 997-1007, 2011.

26. Bonnomet A, Brysse A, Tachsidis A, et al: Epithelial-to-mesenchymal transitions and circulating tumor cells. J Mammary Gland Biol Neoplasia 15: 261-273, 2010.

27. Aktas B, Tewes M, Fehm T, et al: Stem cell and epithelial-mesenchymal transition markers are frequently overexpressed in circulating tumor cells of metastatic breast cancer patients. Breast Cancer Res 11: R46, 2009.

28. Barrière G, Riouallon A, Renaudie J, Tartary M and Rigaud M: Mesenchymal and stemness circulating tumor cells in early breast cancer diagnosis. BMC Cancer 12: 114, 2012.
29. Chen CL, Mahalingam D, Osmulski P, et al: Single-cell analysis of circulating tumor cells identifies cumulative expression patterns of EMT-related genes in metastatic prostate cancer. Prostate 73: 813-826, 2013.

30. Kallergi G, Papadaki MA, Politaki E, et al: Epithelial to mesenchymal transition markers expressed in circulating tumour cells of early and metastatic breast cancer patients. Breast Cancer Res 13: R59, 2011.

31. Thiery JP and Lim CT: Tumor dissemination: an EMT affair. Cancer Cell 23: 272-273, 2013

32. Rhim AD, Mirek ET, Aiello NM, et al: EMT and dissemination precede pancreatic tumor formation. Cell 148: 349-361, 2012.

33. Burgess DJ: Breast cancer: Circulating and dynamic EMT. Nat Rev Cancer 13: 148, 2013.

34. Yu M, Bardia A, Wittner BS, et al: Circulating breast tumor cells exhibit dynamic changes in epithelial and mesenchymal composition. Science 339: 580-584, 2013.

35. Budd GT: Let me do more than count the ways: what circulating tumor cells can tell us about the biology of cancer. Mol Pharm 6: 1307-1310, 2009.

36. Pang R, Law WL, Chu AC, et al: A subpopulation of CD26+ cancer stem cells with metastatic capacity in human colorectal cancer. Cell Stem Cell 6: 603-615, 2010.

37. Herrlich P, Zöller M, Pals ST and Ponta H: CD44 splice variants: metastases meet lymphocytes. Immunol Today 14 395-399, 1993.

38. Sun YX, Pedersen EA, Shiozawa Y, et al: CD26/dipeptidyl peptidase IV regulates prostate cancer metastasis by degrading SDF-1/CXCL12. Clin Exp Metastasis 25: 765-776, 2008.

39. Galizia G, Orditura M, Ferraraccio F, et al: The lymph node ratio is a powerful prognostic factor of node-positive colon cancers undergoing potentially curative surgery. World J Surg 33: 2704-2713, 2009.

40. Chapuis PH, Dent OF, Bokey EL, Newland RC and Sinclair G: Adverse histopathological findings as a guide to patient management after curative resection of node-positive colonic cancer. Br J Surg 91: 349-354, 2004.

41. Edge SB and Compton CC: The American Joint Committee on Cancer: the 7th edition of the AJCC cancer staging manual and the future of TNM. Ann Surg Oncol 17: 1471-1474, 2010.

42. Sobin LH and Compton CC: TNM seventh edition: what's new, what's changed: communication from the International Union Against Cancer and the American Joint Committee on Cancer. Cancer 116: 5336-5339, 2010

43. Galizia G, Gemei M, Del Vecchio L, et al: Combined CD133/CD44 expression as a prognostic indicator of disease-free survival in patients with colorectal cancer. Arch Surg 147: 18-24, 2012.

44. Gemei M, Mirabelli P, Di Noto R, et al: CD66c is a novel marker for colorectal cancer stem cell isolation, and its silencing halts tumor growth in vivo. Cancer 119: 729-738, 2013.

45. Galizia G, Gemei M, Orditura M, et al: Postoperative detection of circulating tumor cells predicts tumor recurrence in colorectal cancer patients. J Gastrointest Surgery 17: 1809-1818, 2013.

46. Hayes DF and Smerage JB: Circulating tumor cells. Prog Mol Biol Transl Sci 95: 95-112, 2010.

47. Wicha MS and Hayes DF: Circulating tumor cells: not all detected cells are bad and not all bad cells are detected. J Clin Oncol 29: 1508-1511, 2011.

48. Elsaba TM, Martinez-Pomares L, Robins AR, et al: The stem cell marker CD133 associates with enhanced colony formation and cell motility in colorectal cancer. PLoS One 5: e10714, 2010.

49. Bourseau-Guilmain E, Griveau A, Benoit JP and Garcion E: The importance of the stem cell marker prominin-1/CD133 in the uptake of transferrin and in iron metabolism in human colon cancer Caco-2 cells. PLoS One 6: e25515, 2011.

50. Du L, Wang H, He L, et al: CD44 is of functional importance for colorectal cancer stem cells. Clin Cancer Res 14: 6751-6760, 2008.

51. Chantrain CF, Feron O, Marbaix E and DeClerck YA: Bone marrow microenvironment and tumor progression. Cancer Microenviron 1: 23-35, 2008.

52. Janni W, Vogl FD, Wiedswang G, et al: Persistence of disseminated tumor cells in the bone marrow of breast cancer patients predicts increased risk for relapse - a European pooled analysis. Clin Cancer Res 17: 2967-2976, 2011. 